\title{
AS ERÓTICAS LACANIANAS \\ E A INEXISTÊNCIA DO OUTRO
}

Ana Lucia Lutterbach Holck

Mestre em

Filosofia, UFMG;

doutora em Teoria

Psicanalítica, URFJ;

psicanalista,

membro da

Associação

Mundial de

Psicanálise (AMP)

e da Escola

Brasileira de

Psicanálise (EBP).
RESUMO: Considerando que, na atualidade, a ordem social sofre uma radical transformação decorrente do declínio da função paterna e dos ideais, e que isto exige a invenção de um laço social diferente do estabelecido nas fórmulas tradicionais, a tese central deste artigo é de que há uma erótica a partir de um novo enlace com o feminino. Definem-se, pois, as linhas que condicionariam essa erótica orientada pela impossibilidade de complementaridade na relação entre os sexos. Os pontos essenciais dessa nova modalidade de gozo são ressaltados com comentários sobre uma situação exemplar retirada da literatura.

Palavras-chave: Erótica, gozo, feminino.

ABSTRACT: Lacanian erotics and non-existence of the Other.The central thesis points out that there is erotic based on new links with feminine, due to the fact that new social encirclements, distant from traditional, are being developed nowadays as a consequence of major changes in social order caused by the fall of paternal functions and of some well established ideals. It also defines the lines which condition this erotic guided by the impossibility of a complementary relation between the two sexes. Stress is made on the basic points of this new kind of rejoice by means of commented example chosen from world literature.

Keywords: Erotic, rejoicing, feminine. 
O impasse sexual secreta as ficções que racionalizam a impossibilidade da qual ele provém.

(Lacan, 1974/2003, p.531)

\section{ERÓTICA E PSICANÁLISE}

Lacan observa que a psicanálise não foi muito longe na investigação de uma erótica, apesar de ter produzido uma importante mudança de perspectiva sobre o amor, e considera que o problema da feminilidade é um dos sinais mais patentes de uma tal carência, um ponto opaco na teoria da sexualidade, como o próprio Freud confidenciou a Jones: "depois de trinta anos de experiência e reflexão, continua havendo um ponto sobre o qual fico sem poder dar respostas: Was will das Weib? O que quer a mulher? O que ela deseja?" (LACAN, 1959-1960/ 1988, p.18).

Essa observação nos instigou a formular as eróticas lacanianas com as seguintes questões: se o problema da feminilidade é um dos sinais de carência de uma erótica, qual seria a função do feminino em uma investigação sobre a erótica? Qual o tratamento dado ao real do sexo e a maneira como se produz o feminino, na erótica do nãotodo?

Em O uso dos prazeres, Foucault (1984) observa que o termo 'sexualidade' só surgiu no início do século XIX. Na antiguidade, os gregos dispunham de um vocabulário para designar práticas de prazer precisas e não havia uma categoria geral que incluísse todas as práticas. Não existia um substantivo que agrupasse numa noção comum o que poderia haver de específico da sexualidade masculina e feminina, mas distinguiam-se claramente dois papéis, o de sujeito e o de objeto, aquele que exerce a atividade e aquele sobre o qual ela se exerce.

A Erótica na antiguidade definia, segundo Foucault (1984), o que deveria ser a relação de um homem com um rapaz, em referência a Eros, para atingir a mais bela e mais perfeita forma e determinar qual uso deveriam fazer de seus prazeres.

A erótica platônica era masculina e prevaleciam as relações entre Eros e verdade. O sexo, apesar de secundário, devia ser praticado entre aqueles que se ocupavam da verdade, e o amor era a estratégia, a via para se alcançar este saber. As mulheres ficavam à parte, se ocupavam de outras práticas, não temos as palavras veiculadas por elas ou entre elas, porque as palavras femininas não produziram um conhecimento, não tiveram registro.

Nos primórdios do cristianismo, realizam-se modificações fundamentais que, em muitos aspectos, regem a moral de hoje. Até Freud, as necessidades sexuais estavam ancoradas na suposição de um "instinto sexual" correlato ao instinto animal, cujo objeto para cada sexo seria o sexo oposto e o objetivo, a reprodução.

Ao propor o termo "pulsão sexual”, Freud subverte essa idéia afirmando que não há nada pré-escrito ou instintivo nas relações entre a satisfação, o objeto e os 
fins da sexualidade, de tal forma que, desde então, toda a idéia de que o sexo é normatizado pela natureza aparece como inconsistente, como se expressa Badiou (2005). Freud faz uma distinção entre o sexual, o genital e a reprodução, e inclui na vida sexual a função de obter prazer em todo o corpo, elaborando uma teoria da sexualidade inédita, inteiramente calcada em sua experiência clínica.

Para Freud, o interesse exclusivo de um sexo pelo sexo oposto não é um fato evidente em si mesmo, tanto quanto a escolha pelo objeto do mesmo sexo. A escolha de objeto não é natural, a pulsão não está determinada pelos atrativos do objeto, nem tem como objetivo, unicamente, a reprodução e a união sexual. Algumas práticas preliminares que se situam no caminho da cópula, como tocar e olhar, são reconhecidas como objetivos sexuais.

Ao contrário da vida erótica da antiguidade, quando se glorificava a pulsão e o objeto ocupava um lugar secundário, Freud (1905/1969) observa que entre nós há uma valorização do objeto e a atividade pulsional é desprezada. No entanto, a origem da pulsão não está determinada pelos atrativos do objeto, estes têm uma importância secundária, o primordial e constante na pulsão sexual é o objeto que se constitui no próprio circuito pulsional.

Na obra freudiana, apesar do amplo desenvolvimento de uma teoria da sexualidade e do termo "erótica” ser mencionado numerosas vezes, este só aparece como qualidade ou caráter de um estado. Não há, em Freud, uma conceituação da erótica enquanto tal.

Nenhum artigo ou seminário de Lacan está dedicado ao assunto e apenas em algumas passagens ele faz referência à erótica, uma delas é a questão do Seminário 7, já mencionada antes. Em outra passagem, dois anos depois, no seminário sobre a identificação, ele afirma que somente se concebe a psicanálise tendo como alvo os fins últimos de uma erótica mas não cabe à psicanálise propagar uma nova erótica. Cabe aos analistas buscar soluções clínicas singulares em cada caso, uma vez que mesmo nas pessoas mais normais “isso não funciona” (LACAN, 14/03/1962).

Assim, para Lacan, tratando-se de psicanálise: sexualidade e erótica não são coincidentes; a erótica condiciona sua experiência mas não cabe à psicanálise propagá-la e não seria possível estabelecer padrões a serem alcançados. E, por fim, “isso não funciona”, isto é, não existem práticas sexuais que garantam um funcionamento regular de um sexo a outro mas definem-se em cada sujeito através de condições singulares de gozo.

Em Freud, o prazer é o funcionamento temperante do corpo e da alma, o nível mais baixo de tensão, sem nenhuma perturbação, um meio termo entre o excesso e a falta. Além do princípio do prazer, Freud detecta a pulsão de morte, uma satisfação que excede ao prazer e, ao contrário da pulsão sexual, produz desconexões. 
Para essa outra satisfação, Lacan (1972-73/1982) introduz um conceito que não é freudiano, o gozo, operando uma transformação sobre o princípio do prazer freudiano de tal maneira que lhe permite afirmar que a realidade é abordada com os aparelhos de gozo.

Apesar de o gozo estar na via aberta pela teoria da sexualidade, Miller (19951996) pontua duas importantes diferenças entre o gozo e a sexualidade freudiana: a libido está orientada pela concepção de desenvolvimento e de etapas, enquanto o gozo é uma libido sem desenvolvimento; a sexualidade seria uma relação de um corpo sexuado a outro corpo sexuado, enquanto o gozo, ao contrário da libido freudiana que circula, investe e desinveste, não é uma relação, aborda o objeto sem se dirigir ao outro, é autístico.

Como não há em Freud e Lacan uma conceitualização para o termo, para efeito dessa investigação, denominamos erótica as diferentes estratégias subjetivas na abordagem do objeto e o enlace com o feminino.

Diante dos impasses atuais decorrentes do declínio da função paterna e da mutação dos lugares do feminino na cultura, perdem eficácia os significantes que asseguravam um ponto de basta para a mulher, uma vez que o próprio ponto não basta mais como tratamento do real. Esse fracasso da função abre um outro espaço circunscrito pela amarração entre os registros, real, imaginário e simbólico, criando formas de enlace do feminino que inauguram uma nova topologia.

A formulação das "eróticas lacanianas" é uma maneira de pensar os laços com o feminino na contemporaneidade, a partir da doutrina dos gozos em Lacan. Para localizar na experiência, essa nova topologia em que há uma prevalência do real sobre o ideal, recorro à experiência literária, escrita com o feminino que, ao se articular como osso quando a linguagem é carne, ${ }^{1}$ torna-se um savoir-faire com a inexistência da mulher.

\section{ERÓTICAS LACANIANAS}

Das modulações do conceito de gozo que acompanharam o progresso das elaborações lacanianas, Miller (1998-1999/2003) estabelece seis paradigmas, ordenados de acordo com os registros Real, Simbólico e Imaginário. Para articular as “eróticas lacanianas" destacamos dois destes paradigmas: o primeiro é o gozo impossível, paradigma situado no Seminário 7 (1959-1960/1988), do qual retiramos nossa questão preliminar. O segundo, o paradigma do gozo da não-relação, refere-se à época do Seminário 20 (1972-1973/1975), período em que Lacan elabora as fórmulas da sexuação e o gozo feminino é especificado.

\footnotetext{
1 'L'écriture n'est depuis ses origines, jusqu'à ses derniers protéismes techniques, que quelque chose qui s'articule comme os dont le langage serait la chair” (LACAN, Séminaire 18: D’Un discours qui ne serait pas du semblant, lição de $9 /$ 6/1971. Inédito).
} 
Segundo Miller (1998-1999/2003), o gozo impossível está no campo do real da Coisa que faz barreira ao imaginário e ao simbólico. Conectado ao horror, é descrito como fora do simbólico e tem um caráter absoluto, está do lado da Coisa, colocada num lugar abissal, um gozo maciço. O gozo impossível é a satisfação pulsional que se mantém fora da significação; o gozo fica reduzido ao lugar vazio, introduzindo a possibilidade de um suplemento para preenchê-lo, que nunca será adequado. Fundamentados neste paradigma, a partir das distintas estratégias para abordar das Ding, identificamos a erótica do amor cortês e a erótica do espaço trágico.

Mais tarde, Lacan substitui o "isso não funciona” do Seminário 9 (1961-1962) pelo aforismo: "não há relação”. Esse aforismo é sua maneira de abordar os impasses contemporâneos quando a sexualidade não está inteiramente regida pela lei do pai e as formas tradicionais de relação não são mais suficientes para dizer o que ocorre no campo do sexo. Neste contexto, ele retoma a ética e a questão freudiana — O que quer uma mulher? — para elaborar as fórmulas da sexuação e o gozo feminino. No paradigma da não-relação, situamos a erótica do nãotodo, perspectiva em que Lacan abandona o trágico e adota a lógica como operador, o desejo perde sua pureza e das Ding dá lugar ao objeto a, estabelecendo uma topologia em que o real não está mais além, mas ex-siste ao simbólico.

\section{ESTRATÉGIAS DO GOZO IMPOSSÍVEL}

Como há no gozo impossível uma clivagem entre o significante e o que está fora da simbolização, o enlace entre o gozo e o Outro realiza-se através de duas estratégias subjetivas em relação à das Ding: a sublimação e a transgressão.

Ao distinguir das Ding na obra freudiana, destacando sua importância como um conceito necessário para o progresso de sua investigação, Lacan assume plena responsabilidade por seu uso.

Das Ding, a Coisa, seria o ponto inicial, anterior a qualquer experiência, vazio onde supostamente esteve o primeiro objeto de satisfação, objeto perdido que preside a busca na experiência de satisfação, em torno do qual se organiza o aparato psíquico.

Nos trilhamentos que se formam a partir da experiência de satisfação e em suas associações com os trilhamentos anteriores, Lacan situa a cadeia significante, edificada a partir da fenda aberta pelo significante no real, uma topologia da subjetividade que se constitui em torno a das Ding: “esse aparato é essencialmente uma topologia da subjetividade — da subjetividade uma vez que ela é edificada e construída na superfície do organismo” (LACAN, 1959-60/1988, p.55).

A sublimação seria uma forma paradoxal de satisfação — pois o gozo é obtido pelas vias aparentemente contrárias às do gozo — - o alvo seria atingido sem recalque, sem apagamento, cingindo a Coisa e não indo ao seu encontro, e sua 
forma exemplar é a erótica do amor cortês, que se mantém no princípio do prazer.

Na transgressão, o gozo estaria, ao contrário, no ultrapassamento das barreiras, propiciando o encontro com a Coisa, campo além do princípio do prazer. Neste caso, as barreiras que fazem obstáculo ao objeto são atravessadas no encontro com a Coisa, especificando um gozo além do princípio do prazer, onde situamos uma erótica do trágico em duas vertentes: de um lado, o gozo veiculado pelo personagem trágico ao realizar o desejo puro, sem nenhum interesse fenomênico, no encontro com a Coisa; do outro, o gozo catártico, o atravessamento do temor e da piedade experimentado pelo espectador diante do espetáculo trágico produzido pela realização do desejo puro.

\section{ERÓTICA DO AMOR CORTÊS}

Na sublimação, trata-se de uma posição em relação à problemática do Outro absoluto, da mulher impenetrável ou, por trás desta, a figura da morte, como nos diz Lacan (1956-1957/1995) no final do Seminário 4: A relação de objeto. É nessa perspectiva da sublimação que Lacan (1959-1960/1988) toma o amor cortês, do começo do século XII, situando aí uma modificação histórica de Eros, forma de uma erótica masculina e princípio de uma moral na cultura ocidental.

O trovador cria o poema ou canto ex-nihilo; não há nada preexistente, e coloca neste nada uma mulher particularizada em seu corpo e sua beleza. Uma maneira de não fugir da Mulher, não fugir desse vazio cruel e enlouquecedor girando em torno desse vazio, cercando-o através da arte de dizer e de cantar. Essa arte do enlace não é uma ascese moral, mas uma criação estética a serviço de uma erótica.

Assim, o amor cortês é um exercício poético no qual o objeto feminino é esvaziado de toda substância real e introduz-se pela privação, pela inacessibilidade. A Mulher ou a Dama é isolada por uma barreira que a circunda, protegendo o sujeito do encontro com o inominável.

No entanto, apesar de a ideologia do amor cortês visar expressamente o lado de exaltação ideal, ele desempenha um outro papel, o de limite, pois sua função é precisamente contornar o objeto, tornando-o inacessível, uma vez que o encontro com a Coisa acarretaria um gozo insuportável, além do princípio do prazer. Seria, como diz Lacan (1972-73/1982), “uma maneira refinada de suprir a ausência da relação sexual, fingindo que somos nós que lhe impomos obstáculo”. É aqui, segundo Lacan, que entra em jogo a função ética do erotismo aludida continuamente por Freud mas nunca formulada. As técnicas em questão no amor cortês articulam-se com os prazeres preliminares dos Três ensaios (FREUD,1905/ 1972), ou seja, certas maneiras intermediárias de se relacionar com o objeto que antecedem o coito e são prazerosas em si mesmas. $\mathrm{O}$ ato de cortejar engendra a 
beleza, esteio do desejo, a regra do obstáculo necessário, da interdição que não é recalcamento do desejo mas, ao contrário, o possibilita.

A regra do amor cortês é assai (JULIEN, 1996), a colocação do amante à prova pela dama. Impõe-se uma demora, é preciso o tempo do bem-dizer, permitindo o nascimento do desejo para que o ato sexual não seja violência.

Segundo Julien (1996), alguns historiadores interpretam o assai como uma recusa do ato sexual, considerando a castidade pressuposta no amor cortês como um meio de evitar 'o ato que o faria perecer', confundindo a castidade cortês com a continência sexual. Assim, a regra do assai, os prazeres preliminares sem o ato sexual, permitiram uma interpretação de que o ato não deveria ocorrer ou que era da ordem do segredo. Semelhante ao lugar da amizade (philia) na Grécia antiga que, situada nos arredores do ato sexual, sua função era preparar, separar, cercar e restringir exteriormente o instante atroz do coito. Mas a philia ia até onde começava o coito (MILNER, 1997).

Porém, interpretado pela via da sublimação, como sugere Lacan (1959-1960/ 1988), a interdição do ato torna-se a própria condição para realizá-lo, pois a interdição desperta o desejo 'purificado' da brutalidade ou da rotina. A sublimação perde, assim, seu caráter freudiano de dessexualização e, associado aos prazeres preliminares, permite um jogo de sedução prévio ao ato, uma preparação de onde nasce, com a fantasia, o suporte do desejo como desejo do Outro. O gozo é domesticado pela beleza que o recobre com seu brilho. Trata-se no amor cortês, como lembra Julien (1996), de enfrentar a crueldade do assai e de conquistar o desejo do Outro.

Ao explicar o fenômeno do amor cortês como uma obra de sublimação, Lacan (1959-1960/1988) pretende explicar como um objeto, a Dama, toma valor de representação da Coisa.

Ao situar a mulher neste ponto de para-além, o amor cortês colocou-a no lugar do ser, o que não lhe concerne enquanto mulher mas enquanto objeto de desejo. Portanto, essa poética não fala da mulher e para a mulher, mas do destino que pode ser dado ao feminino, como um ideal inabordável.

\section{ERÓTICA DO ESPAÇO TRÁGICO}

Referindo-se à razão pura kantiana, Lacan, na Ética (1959-1960/1988), coloca o desejo como totalmente desinteressado, isto é, incondicionado pela sensibilidade, pelos fenômenos. É um desejo sem condição, absoluto, sem finalidade. Com este movimento produz um deslizamento do desejo produzido por um objeto da experiência, para o desejo puro, cujo objeto vazio é real.

Para evidenciar a função do desejo puro, Lacan utiliza as coordenadas do espaço trágico da peça de Sófocles, Antígona. Ação trágica sem qualquer pretensão benéfica, paradigma do desejo purificado do bem e do belo, do desejo como condição absoluta, radical. 
De Sade, Lacan (1960-1961/1991) retira a idéia de duas mortes: a primeira morte estaria ligada ao fim da vida, seu desenlace acidental ou na velhice; a segunda morte é relativa à pulsão de morte e define-se sob a fórmula paradoxal de que o homem aspira a aniquilar-se para eternizar-se, inscrever-se em outros termos do ser, como ocorre no espaço da tragédia antiga. A segunda morte articula-se ao sujeito enquanto barrado pelo significante, numa relação com a linguagem que o obriga como falante a dar conta do que ele é e não é como sujeito.

Antígona levada por uma paradoxal paixão insensível (LACAN, 1959-1960/ 1988), abandona os gestos sensatos, abandona-se à insensatez do desejo puro e, ao se decidir, transpõe o limite dos bens e da felicidade. Algo além desses bens tornou-se para ela seu Bem, nada pode dissuadi-la, torna-se inabalável:

“Essa pureza, essa separação do ser de todas as características do drama histórico que ele atravessou, é justamente esse o limite, o ex-nihilo em torno do qual Antígona se mantém. Nada mais é do que o corte que a própria presença da linguagem instaura na vida do homem.” (LACAN, 1959-1960/1988, p.338)

Lacan (1959-1960/1988) apresenta com a tragédia o desejo do Outro em sua face de desejo fundador de toda a estrutura simbólica, e a face de um desejo da ordem do real, criminoso, sem nenhuma mediação a não ser seu caráter radicalmente destruidor.

Antígona reivindica não os significantes do desejo do Outro simbólico, os significantes de seu destino, da ordem das leis, mas algo que diz respeito à face real do Outro, relativo à Lei da Coisa, desenvolvida fora da cadeia. O significante que a determina está para além da linguagem, puro significante isolado da cadeia que permitiria significações.

Lacan (1959-1960/1988) nos propõe uma topologia do espaço trágico, entre-duas-mortes, limitado por duas barreiras, o bem e o belo, e a aproximação e o atravessamento de cada uma delas indicados pelo temor, culpa ou ódio.

Quando se atravessa um limite, do bem ou do belo, o sujeito penetra no entre-dois do desejo e, se ele retrocede, recua ou renuncia, a tradução subjetiva dessa renúncia é a culpa. Por isso, Lacan conclui que “a única coisa da qual se possa ser culpado, pelo menos na perspectiva analítica, é de ter cedido de seu desejo" (LACAN, 1959-1960/1988, p.382).

A barreira do bem é própria da conservação da vida, do princípio do prazer, relativa aos objetos que imaginariamente realizariam o desejo. Esses objetos surgem para o sujeito em diversas formas: na religião como promessa de um deus redentor, ou no capitalismo nos objetos de consumo - e em todas as coisas que possam alimentar a idéia de um objeto benéfico para garantir a conservação da vida. 
A segunda barreira é a do belo. A função do belo, segundo Lacan (19591960/1988), é precisamente a de indicar o lugar da relação do homem com sua própria morte, e de fazê-lo somente numa fulguração, num brilho e esplendor. O belo nessa concepção não tem nenhuma relação com o ideal.

Na primeira parte do Seminário 7 (1959-1960/1988), o Aristóteles da Ética a Nicômaco é uma referência essencial para pensar uma ética do ideal, mas em seu comentário sobre Antígona, Lacan vai se referir ao Aristóteles da Poética, para buscar o sentido da ação trágica:

“A tragédia é a representação $(\mu \mu \eta\rceil \sigma l \zeta)$ de uma ação nobre levada até seu termo,
e tendo uma certa extensão, por meio de uma linguagem condimentada de espéci-
es variadas, utilizadas separadamente segundo as partes da obra. A representação é
colocada em ação pelos personagens do drama e não há recurso à narrativa; e re-
presentando o temor e a piedade, realiza uma purificação dessas emoções.”
(ARISTÓTELES, p.447).

Num desenvolvimento dessa passagem de Aristóteles em Aristote et la tragédie, Depelsenaire (1988) esclarece que o termo $\mu \iota \mu \eta \sigma \iota \zeta$, mimesis, no sentido trágico, é o isolamento de um traço, um signo e não a reprodução de um paradigma ideal.

A tragédia é representação de uma ação e não o recurso à narrativa, é colocação em ato que produz um efeito de purificação das emoções. O texto de Depelsenaire é particularmente esclarecedor neste aspecto, ao comentar o termo grego $\chi \alpha \theta \alpha \rho \sigma \zeta$, purificação ou catarse. A originalidade de Aristóteles é destacar este termo da tradição do teatro, e tratá-lo não no sentido de exorcismo, pois não se trata de purgação, o que espectador deve realizar é uma substituição do temor e da piedade. A tragédia teria, assim, a função de suscitar, por meio da representação, um prazer legítimo que substitui o desprazer.

Para Aristóteles, a tragédia não é para provocar medo no espectador através de ações suscitando o pavor, a surpresa ou efeitos de horror crescentes. Não importa a experiência patológica do espectador, nem sua edificação moral, o ponto essencial é o prazer que o espectador apreende no espetáculo.

Temor e piedade não estão na tragédia para exprimir as emoções ou para colocá-las em cena, no sentido de imitar, mas emoções que devem ser atravessadas, mediadas pela representação, pelo agenciamento dos fatos representados, pela própria atividade representativa. A emoção trágica não é a emoção bruta ou sensação imediata, é precisamente a emoção purificada.

A imagem de Antígona oferece um prazer decorrente de um apaziguamento do desejo, cumprindo uma função de detenção do desejo e um efeito de entusiasmo. Ao mesmo tempo, o brilho de Antígona tem a função de indicar algo 
irredutível no desejo que o leva em direção à Coisa. Antígona, ao ultrapassar os limites da lei, presentifica uma exigência absoluta, um desejo incomparável, que visa Outra coisa, para além do apaziguamento do registro do princípio do prazer, o gozo da transgressão.

Sob essa perspectiva, Mandil (1993) afirma que a hipótese lacaniana, sobre a beleza de Antígona, deve ser tomada como um efeito da operação de representação articulada pela tragédia como função catártica exercida pelo poder de atração e fascínio advindos da prevalência da imagem da heroína sobre todas as imagens. A imagem de Antígona permite a purificação de tudo aquilo que é da ordem do imaginário, fazendo desaparecer a proliferação de imagens, o que é atingido são as emoções que poderiam estar associadas a estas imagens: "somos purgados [da série imaginária] por intermédio de uma imagem entre outras" (LACAN, 19591960/1988, p.301).

A erótica trágica estaria então, por um lado, na transgressão da heroína trágica, no atravessamento das barreiras e o encontro com esse objeto absoluto, das Ding. Por outro, no atravessamento, por parte do espectador, do temor e da piedade através do efeito da purificação produzido pela representação trágica, cujo resultado é o entusiasmo.

Na tragédia podemos, portanto, identificar duas situações, uma vivida pela heroína e outra pelo espectador. Do lado da heroína é a passagem ao ato, a transgressão das barreiras do bem e do belo e o encontro com a Coisa como pura pulsão de morte. Do lado do espectador é a experiência do atravessamento do temor e da piedade, uma purificação do imaginário que permite um atravessamento sem o encontro com a Coisa, sem identificação e sem passagem ao ato.

Depreendemos, assim, na erótica trágica a transgressão que diz respeito ao personagem e aquela que o espectador experimenta. O herói trágico atravessa as barreiras do bem e do belo visando o encontro com a Coisa, pura pulsão de morte enquanto o expectador, está ex, fora do espetáculo, é atravessamento mas sem o encontro com a Coisa e sua experiência é de entusiasmo.

\section{ERÓTICA DO NÃOTODO}

No paradigma do gozo impossível, como vimos, bordas e limites definem espaços diferentes num mesmo plano e o que está em jogo são os desvios, transgressões e ultrapassagens para se alcançar ou evitar o objeto. Com o objeto vazio, no cerne e na mais radical exterioridade, e o infinito entre-duas-mortes, Lacan traça o esboço de uma topologia, no entanto, este desenho ainda está mais próximo de uma cartografia, ele está apenas delineando o que fará alguns anos mais tarde no campo da lógica e da matemática.

O desejo puro é puro porque é sem o corpo. O gozo impossível, através da 
sublimação ou transgressão, é o gozo sem corpo ou puro encontro com a morte.

No Seminário 20: Mais ainda (1972-73/1982), no qual se encontra o paradigma do gozo da não-relação, Lacan mediu o espaço de gozo sexual com o infinito e demonstrou por que não há a relação sexual, ele ensinou com os conjuntos como a ex-sistência faz o Um e como as mulheres não fazem Um, estabelecendo uma relação ao infinito específica para cada sexo, cuja topologia define os lugares em termos de limite, convergência e infinito: "Neste espaço de gozo, tomar algo limitado, fechado, é um lugar, e falar disso é uma topologia” (LACAN, 1972$1973 / 1975$, p.17).

“Essa questão da relação sexual, se há um ponto de onde isto poderia se esclarecer, é justamente do lado das damas, na medida que é da elaboração do nãotodo que se trata de romper o caminho. É meu verdadeiro tema deste ano, por trás desse Mais ainda, e é um dos sentidos do meu título. Talvez assim eu chegue a fazer aparecer algo de novo sobre a sexualidade feminina” (LACAN, 1972-1973/ 1975, p.78).

No paradigma do gozo da não-relação, neste seminário, a expectativa de Lacan é fazer aparecer algo de novo do lado das damas e seu verdadeiro tema é a elaboração do nãotodo (pas tout), uma estrutura correlativa à face real do Outro, do Outro que não existe. Lacan retoma aí sua questão, que não é mais freudiana, e elabora o nãotodo:

“O que quer uma mulher? Freud adianta que só há libido masculina. O que quer dizer isto? — senão que um campo, que nem por isso é coisa alguma, se acha assim ignorado. Esse campo é o de seres que assumem o estatuto da mulher - se é que esse ser assume o que quer que seja por sua conta. Além disso, é impropriamente que a chamamos a mulher, pois, a partir do momento em que ela se enuncia pelo nãotodo, não pode se escrever. Aqui o artigo 'a' só existe barrado" (1972-73/1982, p.108).

É com o nãotodo que Lacan pretende escrever algo novo sobre a feminilidade. A lógica masculina é a lógica da totalização que se constitui pela exceção como termo que a nega integralmente. Ou seja, para se fazer o todo, sejam quais forem os elementos, é necessário sempre um a mais, que esteja fora. A categoria lacaniana de ex-sistência, designa esse elemento que fica fora, indicando que sempre faltará um significante para que haja universo de discurso.

A fórmula, "para todo sujeito funciona a função fálica, ou, todo homem está submetido à castração”, indica que é pela função fálica que o homem como todo se inscreve, exceto que essa função encontra seu limite na existência de um ponto fora pelo qual a função é negada.

Do lado feminino, o modo de se submeter à lei do falo, à castração, não é postulando a universalidade da lei, como nãotoda a mulher pode se colocar do 
lado do falo ou não. Na fórmula, “não há nenhuma mulher que não esteja submetida à castração”, não há exceção, nenhuma está fora da castração, não existe a figura fundadora de um conjunto de mulheres, logo, não há “nem uma” que não esteja submetida à castração.

Não existe, portanto, a condição necessária para que se estabeleça o universal, o todo não se constitui, logo, a mulher é nãotoda submetida à castração. As fórmulas do lado feminino indicam que a mulher não se inscreve da mesma maneira que o homem, mas ao mesmo tempo, não prescinde da lei do falo. Ela não está fora, mas também, não está inteiramente submetida à lei simbólica.

A incompletude do ser feminino em Freud é tomada em Lacan como inconsistência. A inconsistência designa uma estrutura lógica positiva, o espaço nãotodo, um conjunto aberto definido pela impossibilidade de circunscrever uma totalidade.

O falo e a identificação fálica designam um regime da libido, simbolizada, limitada. Na lógica do nãotodo, o que está em questão não é a falta, o nãotodo não indica o que descompleta o Outro mas a série ilimitada que não é universalizável mas também não é incompleta nem fluída. O gozo feminino infinito, dito nãotodo, designa algo mais frouxo que fluído, um ata e desata, que nunca se deixa amarrar inteiramente.

A época de Freud corresponderia ao reino do Nome-do-Pai, cuja estrutura está esboçada em Totem e tabu (FREUD, 1913/1969), a universalização que se funda com o pai como exceção. A época lacaniana da psicanálise é a época da inexistência do Outro, do nãotodo generalizado, em que o Nome-do-Pai é pulverizado e a subjetividade passa a ser caracterizada pela fuga do sentido, pelo paradoxo da fusão dos gozos, pela segregação e isolamento. A estrutura que responde ao Outro que não existe, não se inscreve na universalização, é o nãotodo generalizado, não no sentido do para todos, mas por toda parte, para todos os lados (MILLER, 1996-1997).

Assim, o Outro que não existe pode ser situado em dois níveis: primeiro, não há universal, não se pode formar o espaço fechado do "para todo x"; em segundo lugar, não há a ex-sistência do Um, o Um inexiste. Essa estrutura do "nãotodo por toda parte”, é o que Miller coloca como o fundamento do gozo no individualismo moderno.

Na erótica do nãotodo, o gozo está sustentado pela essência do significante, gozo Um sem o Outro, o gozo ganha corpo. A sublimação não é sem o corpo, a linguagem é gozo e perde a utilidade, isto é, não visa o sentido. A sublimação passa a ser o gozo na própria realização da escrita. A transgressão é a que a linguagem realiza no corpo, subvertendo seu uso e suas qualidades, criando ilhas de gozo onde não deveria.

Miller (2002) observa que a clínica clássica respondia essencialmente à es- 
trutura da sexuação masculina e se distribuía em função das posições do sujeito em relação ao Nome-do-Pai. A clínica contemporânea funciona na versão do nãotodo. Nessa clínica florescem as patologias que no parâmetro anterior eram consideradas no registro pré-edipiano, centradas sobre a relação com a mãe, ou sobre o narcisismo, e que se tornaram independentes.

Tudo o que é da ordem das adições está na clínica do nãotodo, quando se coloca em valor o sem-limite da série. Observa-se também uma menor efetividade da metáfora paterna e a pluralização dos $S_{1}$, sua pulverização, de tal maneira que se instalou a crise das classificações, e a própria categoria de diagnóstico deixa de ser operatória (MILLER, 2000).

Adotamos a exemplar Lol de O arrebatamento de LolV. Stein (DURAS, 1964), para pensar a clínica atual na versão do nãotodo. Este texto de Duras foi exaustivamente comentado pelos analistas e o termo ‘arrebatamento’ (ravissement) ganhou quase o estatuto de conceito depois do artigo de Lacan (1965/2003, p.198) em homenagem a Duras.

Encontramos em Lol uma solução para a falta de um significante da mulher ou de uma essência da mulher. Ela está sem o pai, sem o Outro, solta de todo e de tudo, é uma mulher se realizando sozinha.

Um pouco de Lol está presente em Barragem contra o pacífico (DURAS, 1950) e O amante (DURAS, 1984), ambas com forte conteúdo autobiográfico, apesar da advertência da autora em Écrire ${ }^{2}$ (DURAS, 1993) de que não existe uma história de sua vida. Nos três casos, trata-se de lidar com o feminino como um real arrebatador, para o qual as barragens são sempre precárias e efêmeras. Mas em Lol V. Stein há uma radicalidade ímpar, ali se "celebra as taciturnas núpcias da vida vazia com o objeto indescritível” (LACAN, 1965/2003, p.205), sem nenhuma concessão às ficções.

O texto de Lol é duro, enxuto, as esparsas informações só fazem uma vida com muito esforço do leitor. Nada na infância de Lol chama a atenção do narrador, ele apenas só sabe que ela nasceu e passou sua juventude em S. Tahla. Seu pai era professor universitário e seu irmão nove anos mais novo, provavelmente vivia em Paris. Tem uma amiga de infância, Tatiana, presente no baile que se repete em todo "Ravissement”, e que terá um papel essencial em sua fantasia.

S. Tahla não está no mapa, Duras em entrevistas a situa tanto na Inglaterra quanto nas praias do Atlântico. Em Lieux, ela diz que S. Tahla e T. Beach "relèvent d'une mer du Nord, la mer de mon enfance aussi, des mers... ilimitées” (BORGOMANO, 1997). Declara, também em entrevista, que mais tarde descobriu a relação que parece evidente entre S. Tahla e Thalassa ('mar', em grego).

\footnotetext{
2 "La histoire de ma vie n'existe pas. Ça n'existe pas. Il n'y a jamais de centre. Pas de chemin, pas de ligne" (DURAS, 1993, p.14).
} 
Doce mas indiferente, Lol nunca parecia sofrer, afligir-se ou derramar uma lágrima. Quando alguém no colégio tentava apreendê-la, ela escorria por entre os dedos das mãos como água (DURAS, 1964, p.24). Em um instante estava longe de todos, imersa não em sonhos adolescentes mas, segundo sua amiga Tatiana, no nada. Conheceu nas férias escolares, aos 19 anos, Michael Richardson, o noivo que será raptado no baile.

A história de Lol não será contada com esses dados, é a partir da noite do baile que o narrador, Jacques Hold, que não estava lá, inventa uma vida com as informações esparsas que recebe de Tatiana e dos rumores que ouve aqui e ali. Ele diz que vai em seu encalço para tentar apreendê-la, no momento em que a mulher de preto atravessa a porta da sala do baile do Casino de T. Beach. Lol não tinha existência antes do baile mas depois ela se torna um deserto, "no qual uma faculdade nômade a havia lançado na busca interminável de quê? Não se sabia. Ela não respondia” (DURAS, 1964, p.24).

Há, na cena do baile, um duplo arrebatamento: o rapto dele e o aniquilamento dela. Ele é raptado por uma mulher feita, vestida de preto e decotada, cheia de mistério, brilho e sedução que chega de repente. Eles dançam e se colam arrebatados. A jovem, se solta do noivo, desfeita e aniquilada, cai no arrebatamento. Lacan resume a cena: “A cena é o arrebatamento de dois numa dança que os solda, sob o olhar de uma terceira, com todo o baile, sofrendo aí o rapto de seu noivo por aquela que só precisou aparecer subitamente" (LACAN, 1965/2003, p.199).

O brilho do vestido preto, que veste e reveste uma, deixa a outra despida do envoltório que a fazia ser e quando desinvestida mostra o brilho da nudez: "O vestido é suporte, tecido, mas o corpo que o porta aspira o sujeito e troca seu estatuto" (LAURENT, 2000, p.19).

O arrebatamento. Arrebatar tem muitos sentidos e todos eles estão presentes na cena: arrancar, raptar, encantar, extasiar, enfurecer, conquistar. Arrebatamento pode ser o efeito da presença daquela que faz A Mulher, para os olhos de outra que acredita que apenas ela não é ou não tem. Arrebatamento é também quando a nãotoda perde seus enlaces e sem norte perde o sentido. Arrebatamento é quando a mulher perde o amor de um homem e este era o único nó que a enlaçava.

Viver não é relatável, mas na escrita de cada época, o tratamento dado ao impossível é diferente. O romance tradicional dá existência ao Outro, criando um universo de sentido mesmo para a infelicidade. Na escrita contemporânea, parece que a prevalência do real sobre o simbólico na amarração entre os registros deixa mais exposto o não relatável do viver. Em O arrebatamento de LolV. Stein, o Outro não existe, não há universo nem sentido, Lol está solta no in-mundo.

Passado o baile, depois de algumas semanas, Lol "parece” voltar a fazer outros laços, casa-se, tem filhos e uma rotina estável, uma vida comum. No entanto, são apenas gestos, sua alma estava irrevogavelmente perdida e a cena do baile se repete 
ainda e sempre sem sentido. É novamente de sua amiga, essa pequena outra, ao lado de seu amante que ela se serve mais uma vez, agora para se revestir com a fantasia.

Depois de perambular por anos, encontra a cena por meio da qual, configurando a erótica do nãotodo, ela se realiza sozinha. Com a arrebatadora Anne Stratter, “A” mulher, a "Outra” realizada, ela fica aniquilada e, com Tatiana, a "outra”, ela recompõe sua fantasia, se realiza. Fora da cena, deitada num campo de centeio ela olha, emoldurados pela janela, Tatiana nua com seu amante envolta apenas nos cabelos que por serem pretos tornam-se propícios para dar roupagem à fantasia de Lol. Ela não está dentro da janela, ela está fora e a vida passa e se realiza na fantasia emoldurada pela janela. Lol "é realizada porque se torna a mancha no espetáculo. Ela não é o voyeur, ela é a mancha” (LAURENT, 2000, p.21).

A "punção" $\diamond$ entre o sujeito $(\$)$ e o objeto a, na fórmula da fantasia $(\$<a)$, indica a função de uma borda que circunscreve um vazio, é a moldura da fantasia que limita e ordena a realidade, uma realidade preponderantemente visual. A moldura da realidade é o que a constitui como tal, é o que na realidade, sendo visual, não se vê, é um limite que opera mediante subtração do objeto a e que organiza o campo do que vemos.

A fantasia vela a subtração do objeto a, o que por estrutura não pode ser visto e, por outro lado, é tela, superfície que suporta o que se projeta sobre ela, sem a qual o desejo é vivido como o abismo da angústia. A função da dinâmica da fantasia é deixar desejar e de forma despercebida determina o sujeito. Lol não se realiza com a fantasia, nem a realiza, só, ela é realizada pela fantasia. Para construí-la, busca em ato e cuidadosamente cada um dos personagens e a moldura para enquadrar a cena que reinveste seu desejo.

Ela não encontra classificação nas estruturas tradicionais, ela é exemplar da clínica atual porque nela a função da fantasia não passa despercebida, não funciona em sua dinâmica mas como estática. Petrificada, a fantasia é cena em ato que, precariamente, a sustenta. Lol faz do amor (Lol V) pedra (stein) e dela própria mancha (stain) no espetáculo.

Recebido em 16/11/2005. Aprovado em 16/8/2006.

\section{REFERÊNCIASS}

ARISTÓTELES (séc. IV a.C./1973) "Poética”, in Os pensadores. São Paulo: Abril Cultural, v.IV.

BADIOU, A. (2005) Le Siècle. Paris: Seuil.

BORGOMANO, M. (1997) Le Ravissement de Lolv. Stein de Marguerite Duras. Paris: Gallimard.

DEPELSENAIRE, Y. (1988) Aristote et la tragédie. Quarto: Bulletin de L’Ecole da la Cause Freudienne, n. 30. Bruxelas, p. 14-20. 
DURAS, M. (1950) Un barrage contre le pacifique. Paris: Gallimard. (1964) Le ravissement de LolV. Stein. Paris: Gallimard. (1984) L'Amant. Paris: De Minuit. (1993) Écrire. Paris: Gallimard.

FOUCAULT, M. (1984) O uso dos prazeres. Rio de Janeiro: Graal.

FREUD, S. Edição standard brasileira das obras psicológicas completas. Rio de Janeiro: Imago.

(1905/1972) “Três ensaios sobre a teoria da sexualidade”, v.VII, p. $119-217$.

(1913/1969) “Totem e tabu”, v.XIII, p. 21-192.

JULIEN, P. (1996) O estranho gozo do próximo. Ética e psicanálise. Rio de Janeiro: Jorge Zahar Editor.

LACAN, J. (1959-60/1988) O Seminário Livro 7, A ética da psicanálise. Rio de Janeiro: Jorge Zahar Editor.

. (1965/2003) "Homenagem a Marguerite Duras pelo Arrebatamento de Lol V. Stein”, in Outros escritos. Rio de Janeiro: Jorge Zahar Editor.

(1972-73/1982) O Seminário Livro 20, Mais, ainda. Rio de Janeiro: Jorge Zahar Editor.

. (1973/2003) “Televisão”, in Outros escritos. Rio de Janeiro: Jorge Zahar Editor.

LAURENT, E. (1999-2000) Aula de 24/05/2000 apud MILLER, J-A. Les Us du Laps. (Lição de Curso inédito)

. (2000) Un sophisme de L'amour courtois. Revue da Psychanalyse de la Cause Freudienne, n. 46. Paris.

MANDIL, R. (1993) "Entre ética e estética freudianas: a função do belo e do sublime na ‘Ética da psicanálise’ de Lacan”. Dissertação de Mestrado, Departamento de Filosofia da Faculdade de Filosofia e Ciências Humanas, UFMG.

MILLER, J-A. (1991-1992) De la nature des semblants. (Curso inédito) . (1995-1996) La Fuite de sen. (Curso inédito) . (1996-1997) L'Autre n'existe pas et ses comités d'éthique. (Curso inédito).

(1998-1999/2003) La experiencia de lo real en la cura psicanalítica. Buenos Aires: Paidós. (1999-2000) Les Us du Laps. (Curso inédito) (2001) Documents préparatoires du Journée du ravissement. Paris: Institut du Champ Freudien.

. (2002) Intuitions milanaises. Mental, n.11. Paris, p. 9-26.

Ana Lucia Lutterbach Holck

bacholck@infolink.com.br 